Journal of Critical Race Inquiry

Vol. 4, No. 1 (2017) pp. 54-73

\title{
The Legacy of Sir John A. Macdonald: How a Historical Inquiry Project Led to an Understanding of Racial Literacy
}

\author{
Terri-Lynn Brennan \\ City of Kingston \\ Tracy Bridgen \\ Limestone District School Board \\ Trevor Hill \\ Limestone District School Board \\ Matt Gallupe \\ Limestone District School Board \\ Meghan Squarebriggs \\ Limestone District School Board
}

\begin{abstract}
The year 2015 saw the City of Kingston, in Ontario, Canada, commemorate what would have been the $200^{\text {th }}$ birthday year of its first Prime Minister, Sir John Alexander Macdonald (hereafter referred to as SJAM). A monumental figure in helping to forge the Canadian nation, SJAM is a figure surrounded by as much praise and controversy as any political figure, both past and present. Although much is said and interpreted as to who SJAM was as a politician and a personal figure, this essay is not about analyzing him or his policies. Rather, this essay looks at how discussions surrounding SJAM are taken up in schools. We argue that SJAM can be used as a racial literacy tool for reading against dominant texts and grappling with personal and institutional implications arising from this critique of dominant texts. In the Canadian context, white privilege is a powerful entry point for engaging students with notions of complicity, accountability and responsibility. We must inform our understanding of the present with a critical trans-historical perspective, challenging popular Canadian misunderstandings of historical racial oppression, such as how we celebrate SJAM
\end{abstract}


for his role in the creation of the transcontinental railway but forget the following: 1) Many Canadians - including government officials - persecuted those who physically built it; and 2) Canada itself is a nation built on the practice of slavery, on one hand, and genocide, on the other. Therefore, with the significance and opportunity of the year 2015, the City of Kingston and the Limestone District School Board opened up an inquiry-based project with 180 students in grades six, seven, and eight regarding their perspectives of SJAM. Responding to their first indepth introduction to SJAM in their history curriculum, the students were asked: "Was Sir John A. Macdonald an Effective Political Leader?" and "Does Kingston Need a New Hero?" Through enriched classroom discussions, exploration of primary and secondary sources and informative academic web conferences, issues of racism, invisible voices, and settler privilege wove a greater and more critical understanding of how racial literacy is imperative in today's schools and classrooms.

Keywords: John A. Macdonald, inquiry-based learning, racial literacy, white/settler privilege

\section{Introduction}

In September 2014, seven elementary school teachers in the Limestone District School Board in Kingston, Ontario took on the challenge of moulding an inquiry-based history project in which their grade six, seven, and eight students were asked "Was Sir John A. Macdonald an Effective Political Leader?" and "Does Kingston Need a New Hero?" These questions emerged from collaborative discussions amongst the seven teachers, the elementary consultant with the Limestone District School Board, and a program coordinator in Cultural Services at the City of Kingston. Over the course of the 2014-15 school year, the teachers and their 180 students utilized these initial framing questions and further developed their own leading questions to expand their students' knowledge and understanding of Sir John A. Macdonald (hereafter referred to as SJAM).

Using an inquiry-based methodology and a critical pedagogical approach to delivering the project's content, the teachers critically questioned SJAM's treatment of and established policies pertaining to Indigenous and Chinese peoples in Canada. This was done by examining such topics as the building of the Canadian Pacific Railway, the Red River Rebellion, Residential Schools and the creation of the North West Mounted Police. A vote taken at the conclusion of the curriculum produced an almost evenly split response from participating 
students about the legacy of SJAM. That is, half of the students agreed that the legacy of SJAM warrants the City of Kingston to recognize the whole of his story and that he was an effective political leader, while half of the students did not agree with this position.

This essay examines how the use of an inquiry-based methodology in history classrooms can provide an effective critical pedagogy when discussing controversial figures and events of the past. This essay argues that conversations about SJAM, defined by whiteness, shaped not only popular celebrations of his legacy but also the educational context in which the teachers led students to place his legacy under critical inquiry. This essay examines this normative whiteness through the topics of effective leadership, acts of assimilation, and racist policies as influenced by SJAM. In conclusion it asks: How can an adoption of racial literacy affect how educators and other voices in positions of privilege influence a systemic decolonizing of classrooms and schools?

\section{Social Theory, Racial Literacy and Critical Pedagogy}

What is the relevance of a conversation about race-or, more specifically, a conversation about race in association with the life of SJAM - that does not fight racism? Analyzing white conversations about SJAM raises some powerful questions about the epistemological operation of whiteness; the mental processes at work in the creation, recreation, and maintenance of white supremacy. Why do white individuals fill up spaces and dialogue through the lens of colonial whiteness? What is the nature of white racial literacy? Is it reflexive? How have white individuals acquired it? What can white individuals learn from the stories of SJAM in relation to whiteness and racial literacy? Looking back on the life of SJAM readily deals in race and racism, but not with it.

Racial literacy, a concept developed by France Winddance Twine (2003), presents one potential approach to unravelling the racial legacy of SJAM. Educators and parents can use racial literacy to teach children to recognize routine forms of everyday racism and to develop strategies for countering and coping with it (Twine, 2003). As Arlo Kempf (2008) uses the 2006 film Crash to analyze the United States racial arrangement that produces tension - rather than, say, solidarity - between different racialized groups, we suggest that SJAM's story similarly "prefers to humanize racism, implying that in the great scheme of things, we are all beautifully and tragically racist - just because" (p. 99) and without modern day fault. White people are epistemologically positioned within their white supremacist society to see/not see, enforce and re-enforce inequity and inequality (Kempf, 2008). When white people interpret the legacy of SJAM, they look for that which they are not, even though they sometimes (or often) recognize that which they are, and "feel really bad", as one often hears. While there is 
nothing wrong with such feeling, when addressing racism it is inadequate, particularly when taken alone and outside of the scope of wider systemic oppressions. As Kempf further suggests, "A strategic socio-political response is displaced by the sheer emotional discomfort to horror white individuals hold... and this dislocation serves to obscure any notion of reflexive accountability for the white reader, teachers, student, etc" (Kempf, 2008, p. 101). White readers of the legacy of SJAM need to dig deeper to understand their inheritance of it within their institutions, communities and individual bodies. Educators and other leaders and teachers in society must engage in a practice to discuss and critically examine race and racism through racial literacy activities, such as investigating the ways in which white people learn to read, acquire, engage with, and disengage from racial meanings in both their individual lives and in the society that maintains them.

For racialized and Indigenous youth to acknowledge and challenge the colonial and racial parameters imbedded within schooling and society, they need an outlet through which they may value and reaffirm their individual identities. They also need to be able to assess and place value on their experiences living as invisible beings in mainstream society, while at the same time moving in from the margins. To do so would directly challenge the Eurocentric voices of institutions that dismiss the knowledge and identities of the marginalized and oppressed. In turn, interpreting and teaching the history of the losers, the marginalized, and the silenced, or those who were not dominant in the areas of wealth, power, or privilege would directly challenge the centuries-long legitimation of white privilege across colonial institutions. Such an approach would lay the foundation for racial literacy and it would challenge the hegemonic alignment of social theory with the academic and political interests of the privileged. Hegemonic knowledge constrains the choice of discourse and prescribes forms of identity and articulation that conform to accepted modes of interpreting theory and employing valid knowledge (Dei, 2000).

Therefore, the critical educator often gets caught in a dilemma: how to support students' questioning and meaning-making, while at the same time teaching students to critique hegemonic power relations that contextualize schools, classrooms and teachers and the limits placed on learning and the acquisition of knowledge (McLaren, 2003)?

Furthermore, if the educator is white, then an implicit tension arises once white people appear under the gaze of discourses of decolonization and anti-racism, which are necessarily informed by the experiences of the oppressed (Kempf, 2008). We have to know who we are and where we are, in order to readjust the lens of privilege and get going someplace else. Teachers and students need to be afforded and need to adopt strategies that challenge the domination of Eurocentric social theories and approaches to acquiring and understanding 
knowledge. Teachers and students need to acquire methods for analyzing their own histories and the cultural politics in which they are embedded that provide a vantage on the forces, relations, and practices that mediate them (Kempf, 2008, p. 26). Teachers need to recognize and adopt a legitimate social theory that promotes facts or truths about social participation and difference within a presentation that is inclusive and equitable (Kempf, 2008).

Routine methods for teaching history are only just beginning to involve any critical thinking skills for teachers or students; these methods have a long way to go toward including approaches to critically examine white privilege and colonial inequalities in texts and curricula. Nevertheless, this emergent shift in pedagogical thinking has led teachers to abandon the white narrative-heavy scripts of textbooks in order to actively explore curricular subjects with their students through the process of inquiry. Although a relatively new practice in Ontario, teaching through inquiry has been a common practice in countries such as Australia and New Zealand for decades. Teaching through inquiry is a methodology that one might argue is in line with Peter McLaren's (2003) argument for a revolutionary critical pedagogy, in which "teachers and students [need to] question how knowledge is produced and ask the following: Who produces it? How is it appropriated? Who consumes it? And how is it consumed?" (p. 31). Challenging oppressive modes of knowing and acting allows social theory to acknowledge the many ways in which people who have been marginalized by colonial systems confront and challenge the multi-generational erosion of their place in history and sense of identity.

Kath Murdoch (2015), a leading expert in inquiry-based teaching, suggests that it is important that "as the inquirer delves deeper and further into the unknown, they regularly pause and return to that first thinking and see it differently." Learning through inquiry starts by posing questions and problems that advance critical thinking skills towards proposing solutions and results. Meeting curricular objectives and expectations by disseminating information through an inquiry process of learning ideally broadens the scope of understanding of how social systems evolved and are maintained. Peter McLaren quotes Henri Giroux in suggesting that "[c]urriculum represents not only a configuration of particular interests and experiences, however; it also forms a battleground where different versions of authority, history, the present, and the future struggle to prevail" (as cited in McLaren, 2003, p.191). Combining an inquiry-based learning approach with a critical pedagogy framework for teaching challenges teachers to approach teaching and learning in a manner that can encompass broader socio-political topics, such as decolonization and anti-racism. Pedagogical theory should provide a lens for understanding the complexity of social dynamics and should emphasize discussion that can compare "what is possible with what exists" (Dei and 
Asgharzadeh, 2001, p. 298). History teachers embracing an inquiry-based approach within critical pedagogy would thus not simply convey knowledge, but would go much further and de/construct knowledge through conscious and unconscious inclusion and exclusion of historical perspectives, contributions and events (Kempf, 2008).

At the beginning of this project, the teachers, school board consultant, and the municipal government consultant grappled over the epistemological approach that should be taken with the known content surrounding SJAM and his life in politics. Importantly, it was not until post-project reflections that a missing critical self-reflective lens was identified and shifted the topic of analysis toward understanding how racial literacy should have been incorporated into discussions surrounding SJAM and how history is taught in general.

\section{The Case Study: The Legacy of Sir John Alexander Macdonald, a Canadian Hero?}

In the fall of 2014, in anticipation of the upcoming anniversary year of SJAM's 200th birthday, 180 Limestone District School Board students, seven teachers and three education assistants began a yearlong inquiry-based history project entitled "Does Kingston Need a New Hero?" As Canada's first prime minister, SJAM holds the distinction of being, for many in the Kingston area, a hometown hero. He was raised in the nearby village of Hay Bay upon emigrating from Scotland in 1820 at the age of five. SJAM was a prominent lawyer and alderman in Kingston in the 1830's and 1840's. Upon becoming a member of the Union parliament in 1844, he began a professional life in politics outside of Kingston, but he remained tied to the locality, given that his immediate and extended family stayed in the region, until his death in 1891 (Dutil and Hall, 2014; Osborne and Swainson, 2011). He was ceremonially interred in Kingston's Cataraqui Cemetery National Historic Site, where his tombstone is a great attraction for all visitors to the region.

While the Kingston of SJAM's time has grown in population and its coverage across a wider stretch of the northeastern Lake Ontario shoreline, the demographic nature of the students and staff involved in this inquiry project would not have looked much different from those of the classrooms of SJAM's day. Two central urban schools, two city fringe schools and one rural remote school over an hour north of the city engaged in this project, and yet the youth who participated represented a fairly homogeneous demographic as typical for this region of the province. Most youth were white, of European background, middle-class, Christian, and English-first speakers. Only 13 of the 180 students identified as being of nonEuropean background, with all 13 identifying as Indigenous/First Peoples. About 45 of the 
180 students would also be categorized within a lower family income range. Partner agencies involved with the project included the Kingston Frontenac Public Library; Queen's University Joseph S. Staufford Library; Queen’s University Archives; Queen’s University Special Collections; Queen's University Aboriginal Teacher Education Program; Queen's University Teacher Education Library; Bellevue House; Rideau Hall and His Excellency; the Governor General David Johnston; Central Block Parliament Hill; Canadian Museum of History; Canadian War Museum; SALON Theatre; St. Andrew's Presbyterian Church; Pump House Steam Museum; Kingston's Tourism Office; Métis Nation of Ontario; the City of Kingston; and the Limestone District School Board. Again, of the supporting agencies that had direct engagement with the students involved with this project, most were led by or populated by white members and participants.

Prior to starting the 2014-15 school year, and following the guidelines of the SJAM inquiry process, the seven participating elementary teachers formulated seven framing questions to guide their instructional approach:

1. What makes an effective political leader? [How do we define "effective" and "a leader"?]

2. Who was Sir John A. Macdonald and what was his goal?

3. What were the significant events happening in Canada at the time [of SJAM] and what was his impact on those events?

4. What were the different perspectives on the issues at the time? Were all voices heard on the issues? To what degree?

5. To what degree did Sir John A. Macdonald achieve his visions for a united Canada? [At what expense was his vision achieved?]

6. What is the lasting impact of his leadership? What is his legacy?

7. Was Sir John A. Macdonald an effective political leader?

Using these framing questions, the teachers provided contextual background knowledge to their students that permitted students to critically analyze, question, and evaluate sources regarding SJAM and to justify their thinking. In the case of Ethan ${ }^{1}$, a student who was identified by his teacher as white, male, and urban middle class, he took a very literal approach to the question of the effectiveness of SJAM's leadership. Ethan felt that the best way to evaluate SJAM was to take all of the information available from all of the different sources and analyze them side-by-side. He made a poster board chart on which he

\footnotetext{
${ }^{1}$ All student names used in this article are pseudonyms and chosen from popular school age names of this time. The teachers provided context to the determination of qualities associated with each student.
} 
discussed - based on Ethan's own moral valuation - some of SJAM's positive and negative actions as a leader, and he then directly compared these actions and judged which held more weight. Ethan's final opinion was partly based on criteria developed in class about leadership, but also on his own self-made criteria for deciding whether building the railroad had more value than the treatment of the Chinese and First Nations to get the job done. Ethan gathered a great sum of historical facts, which included different perspectives on all of the issues and information from many sources. However, in the end Ethan's opinion was based on how he evaluated the lasting effect of each of SJAM's decisions. In a presentation to the class, Ethan was able to clearly articulate why he thought that SJAM was an effective leader, having built the railway and led Confederation, but also not a good leader due to his government's treatment of First Nations, the Chinese Head Tax, and the Pacific Scandal. Ethan's opinion, backed with sources, offered a strong understanding of and ability to critically evaluate multiple issues from multiple viewpoints.

Throughout the evolution of the project, many students began to seek out the "missing" story about SJAM and the unheard voices of those affected by his actions, from his restrictions on immigration to the laws he enacted to assimilate and confiscate the identities and lands of Canada's Indigenous Peoples. Students therefore began to focus their investigations in critically examining such topics as the impacts of the Canadian Pacific Railway, Indian Residential Schools, Confederation, the Pacific Scandal, and other poignant points of interest in SJAM's timeline. For instance, Alfred - a student identified by his teacher as Inuit, male, urban middle class, and who struggles academically - made known to his teacher that he generally chooses not to engage with textbook learning. Through this inquiry process, however, Alfred was exposed to many different viewpoints on many different topics and was much more engaged than he otherwise would have been. Alfred thus found the inquiry process an important way to connect with the information given and find a focus that allowed him to go further. His personal background influenced his connection to the issue of Residential Schools. This allowed him to narrow his focus; instead of trying to sift through the mounds of information from multiple speakers that came to speak to the students, he made a special attempt to ask each speaker what they felt about SJAM's role in the Residential Schools system and how he impacted the schools' policies. Alfred felt that the Residential Schools, for him, were the key to being able to judge SJAM's legacy. Alfred enjoyed being able to choose a hands-on project to present his learning, in the form of a diorama. He was able to produce a much higher quality of work by being able to critically analyze SJAM's role through a very specific lens. 
Although students used an array of secondary sources such as textbooks, credible websites, and documentaries, these sources were not the driving force of the inquiry project. Rather, the secondary sources were used in conjunction with various primary sources, notably academic guest speakers who provided students with multiple, and sometimes conflicting, perspectives on SJAM and the policies and actions he used while "building" the nation. Students were afforded the opportunity to ask critical questions and probe answers offered by expert voices, such as Commissioner of the Sir John A. Macdonald Bicentennial Commission Arthur Milnes, Limestone District School Board Aboriginal Consultant Kevin Reed, Métis curator and Queen's University PhD student Erin Sutherland, and $19^{\text {th }}$ century military historian Steven Smith. Web conferences with University of Ottawa Professor Timothy Stanley and Educational Specialist Alastair Sweeny provided students with further opportunities to evaluate the information presented by guest speakers and formulate their own opinions.

Another student, Steve, identified by his teacher as white, male, and rural middle class, is a verbal learner who excels in debates, speeches and presentations. He became engaged with this project when he listened to Timothy Stanley speak, and specifically when Stanley discussed SJAM as "having a white supremacist vision of Canada" and that he committed "genocide" towards First Nations (see also Stanley, 2016). Steve found this viewpoint to be vastly different and overwhelmingly critical compared with anything he had ever heard about SJAM, and he turned his project into a quest to ask many different sources their opinion on this statement. In particular he had a long, respectful, but very pointed discussion with Queen's PhD students in History and Cultural Studies, whose viewpoints tended to agree with Professor Stanley's comments, which were in conflict with Steve's interpretive findings. Steve's teacher remarked that it was very interesting to see the development of his questioning skills as he learned what types of questions to ask and how to listen to an answer while developing a new question to probe further. He struggled for most of this project with the disconnection between the initial statements that engaged him and the fact that, as he dug further, his own thinking changed, shifting away from believing SJAM was an ineffective leader. In Steve's final opinion, SJAM did not commit genocide, but in fact was fair and appropriate in his policies with Indigenous and Chinese peoples, on the grounds that it was the sustainability of the Canadian nation that SJAM was most concerned. Weighing all the data and conversations he had with said "experts," Steve ended up presenting his findings as a speech, which played to his strengths as a student, and very eloquently defended SJAM as a very effective leader. 
Students were encouraged to seek out primary sources related to their topic and to examine these sources with a critical lens. Students were also provided with a variety of primary sources from the era of SJAM's political career, which included a medical examiner's evaluation of Louis Riel's mental state during his trial in 1885 for treason; first-hand legislative and political report accounts of the treatment of First Nations and Métis Peoples; legislative accounts of the treatment of Chinese immigrants; records on the building of the Canadian Pacific Railway; and maps, photographs and political propaganda from the time period.

Owen, identified by his teacher as a white, male, urban middle class student, particularly flourished on being exposed to the many rich learning experiences afforded him by this project. He began to evaluate the textbooks and other resources regularly used to teach about SJAM and found them lacking many of the voices and viewpoints that he was being exposed to by the expert speakers engaging with his class. Owen felt that textbooks, children's books and many online resources gave only part of the story. He felt strongly enough about the bias in some of these stories that he approached his teachers to remove them from the library. He felt that by not telling the viewpoints of the unheard voices that other students would not have the opportunities to activate their critical thinking skills and develop strong evidence-based opinions. His project, then, was to rewrite a textbook chapter, using the form and style of the textbook used in class, to remedy the issues that he identified. He struggled with keeping his writing concise, given that he had a great deal more to say about each section than previously appeared in the textbook. In the end, Owen's final product was a great example of how inquiry-based learning and critical pedagogical investigations can inspire students to expand their social and theoretical knowledge. Other students wrote children's books that they felt best demonstrated an issue related to SJAM's legacy from a previously unheard viewpoint. For the students to be able to analyze resources and determine what is not being seen or heard, and then develop a contribution they feel is more inclusive, is a true sign of critical thinking.

The teachers provided all of the participating students with various primary quotations by SJAM, such as his announcement to Parliament on 24 March in 1882 that all "Indians" in the territory of Assiniboia must be removed, by force if necessary, from the land south of the proposed railway (McQuillan, 1980, p. 385). SJAM described the use of food control as the strongest aid to forcible transplantation: "We cannot allow them to die for want of food...[W]e are doing all we can, by refusing food until the Indians are on the verge of starvation, to reduce the expense" (as quoted in Lux, 2001, p. 69-70). In a modern account of the time period, author James Daschuk's (2013) choice of language further expanded the discussion for 
the students: "Officials were merciless in their use of food to control the First Nations Population after the decision to use the southern route for the CPR, and...[i]n doing so the Canadian government accomplished the ethnic cleansing [emphasis added] of...its Indigenous population" (p. 123).

In keeping with the critical pedagogical approach, teachers reminded students to ask questions of all voices offering information, as well as to ask themselves, "Whose voice is not being heard in these stories?" For instance, during two web conferences that involved Timothy Stanley and Alistair Sweeny, David, a student from a rural elementary school stated, "I don't know who to believe. This guy (Sweeny) is saying the opposite of what the guy (Stanley) from yesterday said. I am so confused!’ David's comment demonstrated a crucial learning moment: it highlighted his ability to realize that there can be more than one perspective on the same topic, and that delving deeper into the personality of the speaker and their motivation, agenda and intent is as justifiable in research as the recording of "facts." Furthermore, David's comment allowed him to recognize that so long as he could justify his stance with evidence to back up his thinking, it is acceptable to have conflicting viewpoints. A second conversation occurred between students Avery and Madi after they engaged critically with SJAM Bicentennial Ambassador Arthur Milnes regarding the treatment of First Nations by SJAM. Avery and Madi felt that Arthur Milnes had not provided enough evidence during this encounter to support his own argument that SJAM was a friend to the First Nations. This situation demonstrated to both the students and their teacher the importance of formulating an opinion and gathering substantial supporting evidence, and also of challenging the standards that certify "expert" voices. The students interrogated the concept of "expert," the implication that such titles denote, and the systemic agendas at play both for "experts" who have recorded the past and/or who continue to critique the present.

It was at this point in the yearlong project that the sociological issue of race, and in particular racism, was brought to the forefront of the inquiry project. For example, during the discussion about the building of the railway, students were presented with the following quote that SJAM made on the $4^{\text {th }}$ of May, 1885 in the House of Commons:

When the Chinaman comes here he intends to return to his own country; he does not bring his family with him; he is a stranger, a sojourner in a strange land, for his own purposes for a while; he has no common interest with us... A Chinaman gives us labour and gets his money, but that money does not fructify in Canada; he does not invest it here, but takes it with him and returns to China... he has no British instincts or British feelings or aspirations, and therefore ought not to have a vote. (Commons Debates, 1884, May 4) 
This quote was used by teachers as the introduction to the 1885 Chinese Head Tax and sparked debate amongst students as to how racism, interwoven with social and economic marginalization, were open and politically debated in the $19^{\text {th }}$ century. One student was particularly outraged that Canada's first Prime Minster would “openly declare such a harsh and heinous comment towards individuals that were single-handily responsible for linking Canada from sea to sea." The speeches of SJAM led the teachers to expose their students to the concepts of assimilation and/or patronizing ownership by government officials, especially at the time of Confederation.

The students were further presented with the following quote by SJAM as made on May $5^{\text {th }}, 1880$ as part of the Indian Laws Amendment Bill: “...All we can hope for is to wean them, by slow degrees, from their nomadic habits, which have almost become an instinct, and by slow degrees absorb them or settle them on the land. Meantime they must fairly be protected" (Commons Debates, 1880, May 5). Students also read contradictory words by SJAM from this same speech, but offered earlier: “...At all events, the Indians have been great sufferers by the discovery of America, and the transfer to it of a large white population. We are bound to protect them..." (Commons Debates, 1880, May 5). With the introduction of assimilation strategies as used by government officials through the Indian Act of 1876, the students began to engage in issues of racism, and what language and actions qualify to be racist.

Residential schooling brought out the most emotion and passion in discussions on racism for the students. Teachers introduced an 1833 quotation taken from an address by SJAM to the House of Commons:

When the school is on the reserve the child lives with its parents, who are savages; he is surrounded by savages, and though he may learn to read and write, his habits and training and mode of thought are Indian. He is simply a savage who can read and write. It has been strongly pressed on myself, as the head of the Department, that Indian children should be withdrawn as much as possible from the parental influence, and the only way to do that would be to put them in central training industrial schools where they will acquire the habits and modes of thought of white men. (Commons Debates, 1883, May 9) The level of critical inquiry needed to unpack the racism seen in government speeches, policies and acts in the $19^{\text {th }}$ century was very difficult for the teachers to deliver, and even more challenging for the students to fully comprehend. Nevertheless, the topic was broached, and in doing so it allowed the students to reflect on and discuss the various factors, successes, and failures that went into and resulted in the Canadian 
government's creation of the system of reservations and Residential Schools that lasted until 1996.

\section{SJAM as a Tool for Racial Literacy}

The quotes from SJAM, as offered earlier in this essay, were used by the teachers to spark debate amongst their students. However, during both in-classroom discussion and critical analysis of the texts, the words and language employed by the students lacked an imperative to understand the racial and colonial privileges embedded within the sentiments. Upon reflecting on the project's process and products, the participating teachers felt that, although the inquiry-based learning methodology and critical pedagogical approach succeeded in enhancing their students' critical thinking skills and actions, a deep understanding of white settler privilege - the lens through which most students and all teachers filter their learningdid not occur.

A lack of recognition around white privilege and settler colonial ideals became evident at the end of the project when the students answered the initial two questions the project proposed about SJAM. In June 2015, 180 students presented what they had learned through a variety of mediums, which included movies, animation, art, models, infographics, multimedia/scrapbooking, poster boards, songs, and essay writing. Student presentations reflected the project's effort to move beyond the textbook and engage students though a variety of primary resources, diverse guest speakers, and field trips to spaces associated with SJAM, and university/national archives which, together, allowed students to examine a diverse range of views on SJAM's legacy and decide for themselves if he was an effective (political) leader and a hero for Kingston. In response to all the factors revealed, investigated and discussed during this project, $42 \%$ of the 180 students agreed that SJAM was an effective leader for Canada, with $11 \%$ believing him to be highly effective. $6.5 \%$ of students felt he was ineffective, while $4.5 \%$ felt he was highly ineffective. $36 \%$ remained neutral and answered "Not sure" on the question. The question, "Does Kingston need a new hero?" resulted in a relatively evenly split response, with $54 \%$ of students responding "no," and $46 \%$ answering “yes." In response to a logistical question about the students' learning process — "How did your learning of history this year compare to previous years?" - students overwhelmingly responded positively, with 48\% answering "better" and 28\% "much better"; $18 \%$ answered "the same"; $5 \%$ answered "worse"; and 1\% answered "much worse."

Only after the project was complete and an initial essay was written for publication did four of the teachers and the municipal representative (this article's co-authors) begin to reflect on their direction of the content and delivery of this project and their influence on the ways in 
which the participating students took it up. The municipal representative initiated the reflexive conversation on teaching practice, in part because it became evident that her intention to apply an anti-colonial and anti-racist framework to analyzing SJAM and his policies was not effectively explained to the teachers prior to the project's inception. The teachers expressed that they were committed to the inquiry-based learning methodology from the beginning, but that they adopted the critical pedagogical lens and made it an inherent framework only as the project evolved.

Read retrospectively, what this project needed was for its facilitators to turn the lens of critical reflection upon themselves first, so as to better assess how content related to SJAM was being offered to the students. Although she was not in the classroom on a regular basis, Dr. Brennan, the primary author, did have multiple opportunities to share her experience with the 180 students involved in this project. Dr. Brennan self-identifies as a Mohawk-European woman who comes from lower-middle class beginnings, and who in turn has experienced racism and discrimination throughout her life. Her personal analysis of SJAM is one of mixed emotions; she does not hold SJAM personally accountable for the genocidal atrocities inflicted on her ancestors, but rather holds the settler colonial system nurtured and maintained by many privileged men, including SJAM, responsible for the annihilation of Indigenous souls from the land. The classroom teachers of this project, and the four other co-authors of this essay all identify as white settlers who possess colonial and race privileges. During post-project analyses, their exposure to discussions of race, racism, and white settler privilege provided an opportunity to reflect critically on how the project evolved with the benefit of new ways of thinking about privilege and power in the classroom.

As white settler educators in a visibly homogenous community such as Kingston, the teachers who participated in this project came to realize that all aspects of interrogating race and racism need to become part of daily discussion and reflection in classrooms and schools. As Kempf (2008, p. 92) argues, "Whites need to do some thinking about their race, and to address the tensions in doing anti-oppression work; [white settlers] need to continually ask [themselves] three questions: 1. What power do I have?; 2. How did I get it?; 3. What am I doing with it?" Within the answers to these questions may lie some of the necessary epistemological tools for challenging racism. Yet, the asker of these questions must understand that, even if they identify from a place of white settler privilege, doing so does not allow them to disavow being racist, nor argue that they do not participate in white supremacy. To offer up such thoughts is part of a defensive lens through which racial literacy is filtered. In fact, if we turn a blind eye to race, then we turn a blind eye to racial privilege or, as Kempf argues, "As privileged bodies, whites participate in the punishment of non-whites by not 
reflecting on their own privilege" (p. 96). Therefore it becomes imperative for white settlers to constantly reflect on their privilege and on the voices that they use to perpetuate that privilege in all aspects of their daily routine. This is especially the case of educators and other leaders, who are in charge of imparting knowledge, direction and feelings on all things historic and modern.

Students often returned to the notion of assimilation and, applying a modern moral and ethical lens to the concept, wondered how a government could create an assimilationist policy in which the people who had lived on the land for thousands of years were to be deprived of their entire ancestral identities and identifying characteristics. Teachers opened this area of discussion by presenting a value-based movement exercise, in which students were placed in a single line and then moved away from the line depending on how strongly they would answer "yes" or "no" to the following questions:

1. Is it right to physically move people off their own land?

2. Is it right to physically starve these same people after you have moved them off their land?

3. After you have physically moved and starved these people, is it fair to force these people to build a railway on their own traditional lands?

4. After you have physically removed and starved these people, is it fair to force these people to build a railway on their own traditional lands to save a nation from being absorbed by another nation?

This particular line of questioning resulted in the students answering the first two questions easily, with a "no" response and with justification for their thinking. Students were able to provide a clear stance for these questions because they were able to make a personal connection, which enabled them to empathize. However, when discussing the final two questions, students had a more challenging time formulating their opinions. While students were able to value and weigh the actions and words of SJAM's parliamentary statements or policies, white settler students also could disconnect from the implications of their privilege in the actions of "building a railway" and "saving a nation."

Some students admitted their intrinsic belief that "the ends justified the means" by suggesting that without the building of the railway there might never have been the unified Canada we now know. The dislocation or guilt that these same students felt in answering "yes" to questions 3 or 4 could be a result of their limited understanding of racial privilege that even these students still benefit from, 150 years post-railway. But it does need to be noted that of the 180 students who participated in some form of this activity, seven students defiantly maintained a "no" to question 4 . Of those seven students, six were Indigenous. 
It is worth noting that one of the teachers, when announcing the fourth statement, applied a racial literacy approach to critically unpack the use of the word "save." In the context of the fourth sentence in the activity, "save" is meant to concede a patronizing approach on the part of the privileged that are in control of displacing and feeding the people. By substituting alternative words, such as "allow", "offer" or "create", the sentence can take on different inferences that deemphasize who holds the power and control in the action and its outcome. The teacher and the students who unpacked the word "save" were thus able to explore how language can be used to manipulate thought and action, and in turn used this example to critically examine their own identity, privilege and understanding of how the Canadian system has been moulded.

During post-analysis of the project, the teachers discussed their shared experience of initiating this project only knowing what they were taught about SJAM in textbooks during their youth. The content offered through this project opened up a much broader range of facts and impressions that they learned alongside their students. Ms. Bridgen stated, "To be honest, I felt as though I was learning along the way with [the students]." Mr. Hill realized this point "when presenting background on what I knew about Sir John [which I realized] was very little, and what I had learned from Grade 8 history books.” As Ms. Squarebriggs took her Kingston roots into consideration, she suggested, "At the start of the inquiry I'm sure that I presented a rather flattering view of SJAM... my background knowledge of SJAM, which I now realize was one sided, was learned from a textbook, and presented from the white man's perspective."

When the teachers were asked if they were aware of how much their opinions possibly skewed students impressions and ideas, Mr. Hill answered, "For the most part, I tried to remain neutral and hold back my opinion, however at times my true feelings regarding Sir John and Residential Schools emerged... [and] for sure impacted my students' opinions." Each of these teachers was honest enough to acknowledge that their students tended to believe everything that they told them, as when Mr. Gallupe suggested that "as a respected adult in the class [I] would have certainly skewed some students thinking."

When discussing the general embodied power dynamics in a classroom, Ms. Bridgen asserts that, "As an educator, I try to reassure my students on a daily basis that it is okay and important to question things. I encourage them to question [me] and their peers." Referencing her work with her team-teaching colleague, Ms. Bridgen further clarifies that "Mr. Gallupe and I have spent a great deal of time on accountable talk and the respectful language to use when critically thinking about a topic." Many educators focus on respectful language in the classroom, but this approach may not necessarily lead to developing racial literacy. An 
example that arose during the post-project discussion was to compare the sentences, "the nation of Canada was created in 1867" and "the nation of Canada was imposed in 1867"; the teachers were asked if this type of racial literacy was consciously highlighted in discussions during the SJAM project. Ms. Squarebriggs replied, "We never talked about the language that we were using...it didn't enter our thoughts to look at how the language we were using could have had an impact on the presentation of the content."

Further exploring issues of racial literacy, each of the teachers were asked if they thought their white privilege might have impacted their ability to teach this content. Only one of the four teachers felt that their whiteness made things easier for them as a teacher in the Kingston community. The teachers also were asked if they thought that, had their racial identity been non-white, their delivery of the content would have possibly been altered, or taken up similarly or differently by their students? In a reply mirroring Mr. Hill's earlier comments on neutrality, Ms. Squarebriggs indicated, "I presented the facts as I knew them and tried to keep my opinions and emotions out of my lessons. Had I been an Indigenous person I think I would have presented a different set of biases, but there probably would have been more emotions tied to those biases." Mr. Hill also suggested that, "To be honest, we selected topics that were going to cause a stir and make our students uncomfortable and question their learning. As teachers, planning for the inquiry project, we specifically selected topics that were going to be engaging for our students as well as ones that made them uncomfortable."

These teachers were drawn to an inquiry-based approach of their own accord and brought an implicit sense of socially conscious intent to work through this project. However, the post-project discussion on the impact of white settler privilege on the manner in which they presented the content of SJAM's story had each teacher critically take stock and unpack their understanding of colonization and white privilege. Eve Tuck and K.W. Yang (2012) characterize colonization "as the unbroken pace of invasion and Settler occupation, into [Indigenous] lands; where the violence is not temporally contained in the arrival of the Settler but is reasserted each day of occupation" (p. 5). Tuck and Yang (2012) further suggest that as settlers begin to become disturbed by their settler status in social justice frameworks, they try to escape or contain their complicity of inflicting harm, pain or horror on another simply because of "being one's self" (p. 9). As the weight of this reality becomes uncomfortable, Tuck and Yang argue, the natural result of the settlers' guilt is to save and redeem themselves through gifts or leading restorative actions, while not recognizing the patronizing appropriation of these acts as re-victimizing the other. Children and youth are not outside the scope of feeling guilty about white and settler privilege, much like their parents and teachers. 
The way forward is to embrace the need for racial literacy in schools and to continue to have uncomfortable conversations that further examine, critique, and transform racial and colonial privilege and power across Canada.

\section{Conclusion}

As became evident upon post-project reflection, discussing a prominent and integrally Canadian figure such as SJAM produces a crucial need for racial literacy amongst both students and educators in Canada. Currently, much of the teaching in schools about SJAM (and other controversial white settlers) weaves the discussion through key moments within his legacy rather revealing and critically interrogating the structures that he and his governments created to uphold white privilege and Anglo-Canadian culture. Settler privilege and racial responsibility is so foreign to white racial literacy that white people deny them at almost every turn. White privilege creates the condition for its own invisibility, providing a seductive positionality of strategic blindness with respect to its existence and influence across multiple levels of society (Kempf, 2008). Therefore, teachers, parents, government workers and all those who offer knowledge or "expertise" in the history and development of Canada need to adopt a critical understanding of racial literacy and of what it means to be white in today's society.

This project started with the intent to critically engage students, teachers, and associated educational staff through an inquiry-based methodology to investigate the legacy of SJAM in Kingston and as a local hero. In the end, SJAM was also a critical tool to help white teachers assess and recognize how white privilege and the colonial systems that they operate in daily, be it educational institutions, government sector or private enterprise, have scripted our language and action in thinking about race and reacting to racism.

\section{References}

Canada. Parliament. House of Commons [Commons Debates]. (1880, May 5). Official report of the debates of the House of Commons of the Dominion of Canada (Vol. ix). Ottawa: C.W. Mitchell. Retrieved from http://parl.canadiana.ca/view/oop.debates_HOC0402_02/2?r=0\&s=1 
Canada. Parliament. House of Commons [Commons Debates]. (1883, May 9). Official report of the debates of the House of Commons of the Dominion of Canada (Vol. xiv). Ottawa: Maclean, Roger \& Co. Retrieved from http://eco.canadiana.ca/view/oocihm.9 07186_1_2/2? $\mathrm{r}=0 \& \mathrm{~s}=1$

Canada. Parliament. House of Commons [Commons Debates]. (1885, May 4). Official report of the debates of the House of Commons of the Dominion of Canada (Vol. xviii). Ottawa: Maclean, Roger \& Co. Retrieved from http://eco.canadiana.ca/view/oocihm.9 $07186 \_3 \_2 / 2 ? \mathrm{r}=0 \& \mathrm{~s}=1$

Daschuk, J. (2013). Clearing the Plains: Disease, politics of starvation, and the loss of Aboriginal life. Regina, SK: University of Regina Press.

Dei, G.J.S., \& Asgharzadeh, A. (2001). The power of social theory: The anti-colonial discursive framework. Journal of Educational Thought, 35(3), 297-323.

Dei, G.J.S. (2000). Recasting anti-racism and the axis of difference: Beyond the question of theory. Race, Gender \& Class, 7(2), 38-56.

Dutil, P., \& Hall, R (Eds.). (2014). Macdonald at 200: New reflections and legacies. Toronto: Dundurn.

Kempf, A. (2008). On the souls of white folks: Notes on the white "Crash" conversation. In G.J.S. Dei \& P. Howard (Eds.), Counterpoints, Vol. 339, Crash Politics and Antiracism: Interrogations of Liberal Race Discourse (pp. 91-109). Toronto, ON: Peter Lang.

Lux, M. (2001). Medicine that walks: Disease, medicine and Canadian Plains Native People, 1880-1940. Toronto, ON: University of Toronto Press.

McLaren, P. (2003). Life in schools: An introduction to critical pedagogy in the foundations of education ( $4^{\text {th }} E d$.) Boston, MA: Pearson Education.

McQuillan, A.D. (1980). Creation of Indian Reserves on the Canadian Prairies, 1870-1885. Geographical Review, 70(4), 379-392.

Murdoch, K. (2015, August 18). Tuning in...to tuning in [Blog post]. Retrieved from http://www.kathmurdoch.com.au/blog/2015/08/18/tuning-in-to-tuning-in

Osborne, B.D., \& Swainson, D. (2011). Kingston, building on the past for the future. Kingston, ON: Quarry Press.

Stanley, T. (2016). John A. Macdonald, the "Chinese" and Racist State Formation in Canada. Journal of Critical Race Inquiry, 3(1), 6-29.

Tuck, E., \& Yang, K.W. (2012). Decolonization is not a metaphor. Decolonization: Indigeneity, Education \& Society, 1(1), 1-40. 
Twine, F.W. (2003). Racial literary in Britain: Antiracist projects, Black children and white parents. Contours: A Journal of the African Diaspora, 1(2), 129-153. 